\title{
Readymade or Made [to be] Ready, Replicant or Surplus: Social Reproduction and the Biopolitics of Abstraction Prefigured in Contemporary Art
}

\author{
Jaleh Mansoor \\ $U B C$
}

Follow this and additional works at: https://docs.lib.purdue.edu/clcweb

H.

Part of the American Studies Commons, Comparative Literature Commons, Education Commons, European Languages and Societies Commons, Feminist, Gender, and Sexuality Studies Commons, Other Arts and Humanities Commons, Other Film and Media Studies Commons, Reading and Language Commons, Rhetoric and Composition Commons, Social and Behavioral Sciences Commons, Television Commons, and the Theatre and Performance Studies Commons

Dedicated to the dissemination of scholarly and professional information, Purdue University Press selects, develops, and distributes quality resources in several key subject areas for which its parent university is famous, including business, technology, health, veterinary medicine, and other selected disciplines in the humanities and sciences.

CLCWeb: Comparative Literature and Culture, the peer-reviewed, full-text, and open-access learned journal in the humanities and social sciences, publishes new scholarship following tenets of the discipline of comparative literature and the field of cultural studies designated as "comparative cultural studies." Publications in the journal are indexed in the Annual Bibliography of English Language and Literature (Chadwyck-Healey), the Arts and Humanities Citation Index (Thomson Reuters ISI), the Humanities Index (Wilson), Humanities International Complete (EBSCO), the International Bibliography of the Modern Language Association of America, and Scopus (Elsevier). The journal is affiliated with the Purdue University Press monograph series of Books in Comparative Cultural Studies. Contact: <clcweb@purdue.edu>

\section{Recommended Citation}

Mansoor, Jaleh. "Readymade or Made [to be] Ready, Replicant or Surplus: Social Reproduction and the Biopolitics of Abstraction Prefigured in Contemporary Art." CLCWeb: Comparative Literature and Culture 22.2 (2020):

<https://doi.org/10.7771/1481-4374.3844>

This text has been double-blind peer reviewed by $2+1$ experts in the field.

The above text, published by Purdue University Press (CPurdue University, has been downloaded 0 times as of 08/02/ 20.

This document has been made available through Purdue e-Pubs, a service of the Purdue University Libraries. Please contact epubs@purdue.edu for additional information.

This is an Open Access journal. This means that it uses a funding model that does not charge readers or their institutions for access. Readers may freely read, download, copy, distribute, print, search, or link to the full texts of articles. This journal is covered under the CC BY-NC-ND license. 


\section{PURDUE}

UNIVERSITY PRESS < http://www.thepress.purdue.edu>

\section{CLCWeb: Comparative Literature and Culture}

ISSN 1481-4374 <http://docs.lib.purdue.edu/clcweb> Purdue University Press @Purdue University

CLCWeb: Comparative Literature and Culture, the peer-reviewed, full-text, and open-access learned journal in the humanities and social sciences, publishes new scholarship following tenets of the discipline of comparative literature and the field of cultural studies designated as "comparative cultural studies." In addition to the publication of articles, the journal publishes review articles of scholarly books and publishes research material in its Library Series. Publications in the journal are indexed in the Annual Bibliography of English Language and Literature (ChadwyckHealey), the Arts and Humanities Citation Index (Thomson Reuters ISI), the Humanities Index (Wilson), Humanities International Complete (EBSCO), the International Bibliography of the Modern Language Association of America, and Scopus (Elsevier). The journal is affiliated with the Purdue University Press monograph series of Books in Comparative Cultural Studies. Contact: <clcweb@purdue.edu>

\section{Volume 22 Issue 2 (June 2020) Article 9 Jaleh Mansoor, \\ "Readymade or Made [to be] Ready, Replicant or Surplus: Social Reproduction and the Biopolitics of Abstraction Prefigured in Contemporary Art" $<$ http://docs.lib.purdue.edu/clcweb/vol22/iss2/9>}

Contents of CLCWeb: Comparative Literature and Culture 22.2 (2020)

Special Issue The Politics of Social Reproduction. Ed. Kelly Gawel and Cinzia Arruzza <http://docs.lib.purdue.edu/clcweb/vol22/iss2/>

Abstract: The artist may be one of the last subject-positions within capitalism to determine their own labour under the sign of "creativity," and to be held at an oblique angle to value productive labour; they are dialectically "free" to be creative (Adorno, Vishmidt, Stakemeir, Beech). But since 1973 if not 1915, artists mark this creative capacity as a process whereby reification has migrated from that of the object to that of the subject, to the artist-subject, now heightened in a post-industrial era of "feminized" and immaterial labour where service eclipses production. Artists in the "post medium condition" elaborate practices that track parallel to the service economy and yet continue to be mythologized as agents capable of delivering exceptional experience, an experience institutionally deemed to be specialized and singular.

Artist Santiago Sierra mobilizes and elaborates delegated performance art with avowed and explicit reflexive cruelty to raise the contradiction inherent in the expectation of exceptional content delivered by free and creative agents to query the question of collective agency in instances where persons are expelled by the labour market in relation to state status. 33 Persons Paid to Have their Hair Dyed Blonde from 2001 dramatizes not only the global class war inherent in racialized stateless surplus populations in the context of collapsing social contracts set by the Keynesian state and operative from the 1930 s to but the degree to which these populations come to be seen as less-than-human, as less than bearers of labor-power, but as disposable. 


\title{
Jaleh MANSOOR
}

\section{Readymade or Made [to be] Ready, Replicant or Surplus: Social Reproduction and the Biopolitics of Abstraction Prefigured in Contemporary Art}

\begin{abstract}
"The Abstractions underlying them [i.e. social relations] are of a completely different kind; they are found given, ready-made." Alfred Sohn-Rethel. Intellectual and Manual Labor: A Critique of Epistemology. Macmillan Press, 1977.

"Joseph Stiglitz, the left economist, estimates that 'human capital' now represents between 2/3rds and 3/4ths of the total capital - which tends to confirm Stalin's unironic title: 'Man, the Most Precious Capital.' According to Locke, 'Man has a Property in his own Person. This no Body has any Right to but himself. The Labor of his body, and the Work of his Hands, we may say, are properly his' (Treatise of Civil Government), which in his mind did not rule out either servitude or colonization...man was the owner of something he could alienate while remaining intact. He was formally something other than what he sold....now we are witnessing a change of regime in the economy. The Majestic figure of the worker is being succeeded by the figure of the Needy Opportunist because if money and control are to infiltrate everywhere, it's necessary for money to be lacking everywhere." The Invisible Committee. Now. The MIT Press, 2017.
\end{abstract}

"[In the neoliberal art market], art and labor, creativity and training, become harder and harder to tell apart. The growing proximity between art and labor starts to emerge as a zone of indistinction." Marina Vishmidt. Speculation as a Mode of Production. Brill, 2018.

Over the weeks in which the present text was drafted, the US carceral state accelerated the policies strategically engineered to adjudicate the value of individual and collective human life, brutally disarticulating the last limits of common social relations (those between children and their adult caregivers and among families and communities). It also at once openly, brazenly performed the disposability of global surplus populations while forming future reserves of labor power forged by and fully dependent on the state. Most of the immigrant children separated from their caregivers will be in and "processed" by the state; those who remain dislocated are equally contingent on state determination as a result of their indeterminacy. The Trump administration's "zero tolerance" at the border policy not only divided bodies, mostly those of children from their caretakers, in a form of cruelty foundational to the modern state (examples of this abound from the Residential Schools imposed on the indigenous peoples of Canada to the division of slave families by the market and beyond), but re-opened the question of market mediated and unmediated labor, the state's role in those forms of mediating the appropriation of labor power and finally the part played by racialization in the development and management of surplus populations comprised of reserve armies of labor, of bodies disarticulated from any form of survival outside state mediation of labor and of those deemed unable to work. Children divided from their caregivers constitute both senses of surplus population. They are unemployable and mobilized as tokens to manipulate adults into relinquishing their own civil statuses, deemed equally unemployable or a threat to employable white labor power (or tragically a kind of unknown quotient absorbed into the entropic opacity of everyday life), and sought and tracked by the state as the only form of "care" or "accountability" open to these separated persons, its captive and therefore inevitable future workers.

In June 2001, Spanish artist Santiago Sierra collected 133 men to take part in his project for the Spanish Pavilion at the 49th Venice Biennale. Sierra's "action," entitled 133 Persons Paid to Have their Hair Dyed Blonde, took place on the opening day of this auspicious art world event. The criteria in selecting the men were as follows: they were to originate from Africa, Asia, or the Middle East and have dark hair. The participants were immigrants and refugees, legal or otherwise. Sierra directed the 133 men to an area in the Arsenale where he bleached their hair, producing a visibly artificial appearance, in effect marking each person as though with a yellow highlighter. The self-assigned role of the artist was to collect, direct and manage these persons within the spatial parameters of the Arsenale only, in the institutionalized framework of the art exhibition, in front of an audience watching the transformation. The yellow headed 133 persons then dispersed, returning to their everyday activities: predominantly illegal street vending on and around Piazza San Marco, a form of survival and daily self-replication paradoxically endangering these specific men, rendering them vulnerable to the police and carceral state apparatus threatening to either detain or deport them. This defenselessness before the law doubles back to re-qualify the at first superficially generous proposition by the artist of offering the men money for very little time and effort; for it very rapidly becomes clear that the men are paid to risk their lives, that this seeming generosity for little labor is in fact a meager sum in exchange for a gamble with formal freedom. They were compensated nominally to be made exponentially more vulnerable, because now 
they are hyper visible to the police. The paid volunteers took no part in determining the unfolding of events, nor did they become actors in a production. Acting, understood as either the delivery of dramatic content elaborated within the framework of theater, situated in the fact-bearing framework of documentary practices and reenactments, or framed as explorations of agency as in Actionism or neoavant-gardist task performance, was demonstrably irrelevant to the situation. The realization of any form of agency on the "volunteers" part was not only irrelevant, but shown to be structurally unattainable. They had no role in driving a narrative forward or delivering content. This was not that kind of "performance."

In this essay, I argue that Santiago Sierra mobilizes the genre of performance art, a genre already saturated in the contradictions of exploitive remuneration and the shifting nature of labor in the exponential rise of the service sector, in order to query the particular strategies of a racialized dynamic nested within the labor-capital relationship and the equally racialized extraction of labor-power from surplus populations. Surplus populations also include those demographics held in reserve for their labor power but formally unemployable, thereby held in a contradiction designed to distribute the very value of human life, and, within the brutal parameters of capitalism, its very right to valorization. The extraction of surplus from labor-power, the economic dimension of the social equation, is supported by a tacitly political dimension. Labor power is mediated by forms of governance that adjudicate the mediation of the sale of labor power. Governance-we may call this "the state" for shorthand-must first ascertain that some of its demographic composition is "free" to sell its labor power, a freedom predicated on the unfreedom of others, often women, whose labor is re-naturalized. This is the insight articulated most succinctly by Selma James and Mariarosa Dalla Costa in The Power of Women and the Subversion of the Community: "The unfree patriarch was transformed into the 'free' wage earner, and upon the contradictory experience of the sexes and the generations was built a more profound estrangement and therefore a more subversive relation" (24). The key point here, at once critically expanding on lacuna in Marx's analysis and contributing to a larger structural understanding of the totality of capitalist social relations, is that any given labor pool is divided into those mediated and those unmediated by a wage. This form of mediation is then rationalized by deference to categories of identity that retroactively legitimate this division and which in turn become axes not only of gender assignation but also of racialization and racial categories reticulated to value or its lack (Gonzalez). Turning around in logic, it is then re-articulated in the social field as a matter of political "freedom," among the rights and freedoms enjoyed by the citizen, the right to work and to have the fruits of one's labor power assigned value on a market.

Yet the phrase "right to valorization" is already a contradiction until forms of governance re-naturalize it. For as Marx noted, human beings are the proprietors of their own labor power. And yet we see everywhere forms of enclosure and determination on the part of the state that disarticulate this proprietorial relation with the self, substituting for it the will of the state.

To what extent have art practices of the last decades prefigured this process, either in warning, in indifference or in what Hal Foster refers to as the "mimetic exacerbation" of the artist to the hegemon in which he works? While the central problem set of Sierra's piece at Venice, highlighted among the highlighted heads, was visibility itself (and who or what constitutes visibility as a person in a social regime founded on the uneven value of labor-power within a state-sanctioned international division of labor), the prefigurative function of this spectacular demonstration offered within the parameters of cultural and aesthetic (rather than political) praxis needs to be specified. Now that the global and systemic structure of capital has changed dramatically over the long downturn of 1973-2008 and its ramifications, including the location of cheaper labor power in peripheral states and capital's flight from its former core to extract it, the lines of mediation between capital and culture must also be remapped. To pose my argument as a question, given that the economic reconfiguration on which culture depends has changed drastically: why are there so few accounts of the restructured global relationship of capital and labor? What of the emergence of a new composition of a global underclass (in the absence of proletarians forged in common geopolitical and historical frameworks) in writing about art and social justice?

\section{Art and The Totality}

Sierra's work starkly demonstrated openly invisible labor relations in a heightened state-to-market relationship in which immigration is at once necessary and xenophobically restricted, compounded by the adjudication of the value of labor power along racialized lines. This attenuated observation of how bodies are assigned value by the state and the market, the central concern afforded by Sierra's project, supersedes a number of impasses within the discourse of intersectionality, as I will show, but it does so from the perspective of aesthetic praxis, a mode of inquiry radically other to social science. As such, 
Sierra's aesthetic query performs (and prefigures, as I note at the opening of this essay) the mutually constitutive operations of proletarianization and racialization, or rather the way in which race is doubly coded by capitalist ideology to maximize the efficiency with which the extraction of labor power is accomplished and valorized. At the same time that his aesthetic project demonstrates the ways in which the state apparatus engineers the market's un/mediated wages, it equally reveals the vacuity of the ethical project on which modernity and its ideal political form, democratic equality, were forged. In other words, Sierra highlights the symbiotic bond between classic forms of social reproduction in the state's production of both a proletarian reserve and a growing racialized surplus population in the equally changing dynamic between the once capitalist core and its "periphery."

While discursive limits have produced a mutual blindness on the part of Marxist analysis and of postcolonial and identity-oriented frameworks, resulting in a failure to delineate the way in which capital extracts labor power from those it most denigrates and devalues on a symbolic register - that is to say, how matters deemed "identitarian" assist in the double exploitation of labor by capital - the cultural enactment of our contradictory conjuncture crystallizes with rare lucidity. This essay will engage some of that discourse.

Even though the contradiction between the primacy of race and class may or may not express itself in the social political register, that contradiction is doubly necessary to capital; it assists capital by coercively driving down the value of labor drawn from deracinated, migrant and refugee populations, or equally racialized surplus reserves and buying them back at a price point cheaper than their racially validated competition.

I argue, via Sierra's practical demonstration, which isolates and explores forms of social abstraction that are not immediately accessible or transparent to discourse, that the labor-capital dynamic in late capitalism must appear at first to act in its own disinterest, to divide and distribute and devalue bodies which it must then not only track but pay for, in order to meet its rapidly changing demands in a changing core and periphery dynamic in the globalized neoliberal era. What emerges from Sierra's cruel praxis is a paradox at the core of labor under the current stage of capitalism. Paradoxically, forms of oppression that limit access to social wealth (the wage for instance), are symbolically mobilized as a means by which to extract labor power more cheaply or more brutally. The most oppressed demographics are exploited in ways that are markedly different from those proletarianized demographics drawn from the settler colonial state, which continued to arbitrate the circulation of value and labor power from core to periphery and back in the aftermath of decolonization. The double bind between oppression and exploitation increasingly describes the condition of demographics across the globe, over who are equally devalued for cheap labor power, as well as those deemed no longer valuable to capital, in excess of its capacity to absorb labor power into the machinations of profit, deemed thereby "surplus." First and foremost, Sierra's work forefronts the importance of the transaction. As I will argue, the transaction, in turn, is shown to be the arena within which dehumanization takes place, under the guise of the most civil and indeed natural forms of engagement.

The logic of Sierra's action rested on the suspension of agency of any kind on the part of these 133 persons, while placing instead the kernel of motivation for anything that might happen thereafter, for the ensuing results onto the body's susceptibility to structure (state apparatus, cold, hunger, danger). This displacement of causality from agency to structure is denoted by criteria set to the lowest denominator of physical characteristics pegged to racial and ethnic alterity. Any delivery of a subjective or situated interpretation of the circumstances was eclipsed by a demonstration of the objective social relations determining the scenario: a demonstration - played out over the bodies of these men - of the global state and market relations setting the basic condition for the possibility of what was happening, occurring openly and for display before the widest possible public audience, at Venice.

Sierra's way of isolating and mobilizing a reductive transactional logic heightens an open secret: The state categorizes bodies along these axes of capital and labor power, adjudicating legal replicability (utility of labor-power to the state and the state's reciprocal protection) and /or surplus status. While the state builds and manages its reserves, the individuals who constitute it are contingent for survival on the state's mediation of labor. ${ }^{1}$ Sierra exaggerates and mimics this asymmetrical relationship between him and his "volunteers" (Foster). The act of remuneration in this instance becomes Sierra's very medium, mobilized to test the paradoxical form of abstraction invisibly stamped on human flesh in the market-as-social field that silently regulates everyday life, forming limits to perception itself. Put more ambitiously, Sierra highlights at once the market through which labor power is abstracted and the

${ }^{1}$ State mediation of the labor-to-capital ratio has a long history, the task of which it is not the purpose or scope of this essay to address. One immediate example, however, might be the Canadian processing of Chinese immigration in the late nineteenth century. See Belshaw. 
way in which this form of abstraction marks bodies as excessive to social order. In this aesthetic order organized around the transaction, an idiom allegorical and metonymic, the way in which surpluses in excess of the legally managed labor pool are all the more distributed and disbursed by the biopolitical order becomes clearer. The opposition between proletarianization and criminalization is revealed as a tenuous one bearing on the contingencies of capital's flight. Of interest here is the way in which the men's abandonment by a regime that distinguishes the disposable (illegal) from the useful (legal) presents them as a peculiar form of fetish, a fetishized form of labor power disarticulated from the legal and juridical status that would establish their status first and foremost as human. "Marx made 'man' the proprietor of his 'labor power' - a rather mysterious metaphysical entity when you think about it" (Invisible Committee 99). The transactional gesture pressures the limits of the Marxian formulation of the relative "freedom" the bearer of labor power has to sell that power.

Sami Khatib's exploration of the status of the human as bearer of labor power within capital attempts to both clarify and expand Marx's view. I borrow from Khatib's isolation and elaboration of one problemset in Capital, that of the paradoxical autonomy from and indifference to social relations on the part of the value-form, to query the limits of the category (labor power) as a function of the market, the labor market specifically. The task here is to trace the way in which labor power is extracted from human support, which is severed from the social relations that give rise to it, and reified as a commodity, which then translates into quantified value through market transaction. Addressing the "thingishness" of modernity in an essay in the volume Aesthetic Marx, Khatib writes "In capital there is no Grundswesen, no foundational grounding essence that could be concealed (reified), but on the contrary, the objective thingish mode of concealment itself has become the essential feature, the Grundswesen of society" (66). The social relation is itself the support of a model of the individual subject useful to capitalist social relations, a [tautological] social technology or techne of replication and reproduction as indifferent to human agency as the signifier or the value form. Khatib notes, echoing The Invisible Committee's point in the epigram to this essay that Marx's category of labor power is a curious metaphysical variable: "Value and its substance (abstract labor) can neither be grasped in concretely spatial terms of sensuous materiality (a quantum of simple or average labor) nor in temporal terms of chronometric time (measured by days, weeks, and hours) but only as a purely social relation devoid of all material-empirical traces" (57). ${ }^{2}$ The objects produced by accumulated labor power (commodities) are split and divided across any number of abstractions (quantified time, measured space) in the production, distribution and consumption phases. But this condition is mirrored in the bearer of labor power, the "subject," whose time is congealed in the object alongside any number of other workers' time even though the agreement at the moment of the sale of labor capacity is understood to be undertaken in self-interest. Self-interest and the formal "right" to self-replication are mapped onto one another, the latter gaining dominance in a process wherein the worker believed himself to be an agent. In short, the contractual aspect of the deal is separated from the spontaneous and "voluntary" present, just as the consequence in the social order (in this instance radical vulnerability before the law in a carceral context) is cut off from immediate material gain of getting paid; the choice comes down to self-reproduction via material intake with a possibility of imminent incarceration or actual liberty and starvation. ${ }^{3}$ Sierra queries Marx's "man" as proprietor of his labor power. The social dynamic of an economy resting on labor that its bearer is at once "free" in juridical terms to sell but obliged or compelled to place on the market in material terms, is an a priori one in which the individual bearer is set against his own interests, either on the side of "freedom" or on the side of material daily self-replication.

But a question remains, one that forms a secondary inquiry of this essay: how did this "thingishness" move from actual things, objects mediating social relations, to the becoming thingish of all personhood and experiential life? In culture, performance art has ascended over the last several decades as the central culturally mediating category. Performance, unlike media based forms, requires a minimum of one person to act as the support for the delivery of content. Although it is set into circulation to denote any number of art practices involving human actors and agents, very few of those practices entail performance in the sense of theater or expression. ${ }^{4}$ Many of these practices explore the human as a

2 For instance, quality precedes quantity, "but in real time quantity seems to come first" (Khatib 51).

${ }^{3}$ On the sadism of "choice" in a neoliberal labor market context, see Vishmidt, Speculation: "The contractual aspect is split from the voluntary 'now'" (32). So, while "it is crucial to distinguish the unpaid intern in a cultural centre from the artist producing commodities or 'just research' for an uncertain market, in either case the valorization of creativity is a mode of producing subjectivity that aligns the interest of workers with the speculative nature of capital, a way of installing speculation at the most intimate level of subjective existence" (39).

${ }^{4}$ On the origins of performance art in the context of Fluxus, Happenings and other such post-war forms that broke with the canvas and pedestal, see Rodenbeck. On performance, see also Jones; and Goldberg. On the dominance 
non-agent, a cipher to structure, motivating the queer feminist artist Yvonne Rainer's term exploitive voluntarism. ${ }^{5}$ This term "voluntarism,' applied by Rainer to Marina Abramovic's practice, which stands at the historical beginning of the genre and which often involves the inclusion of bodies reduced to their exposed physical presence, makes a joke of its own technical meaning by negating the very possibility of real agency, capitulating to coercive structural determinations necessary to daily self-replication (survival) under capitalism. In Rainer's terms

Ms. Abramovic is so wedded to her original vision that she - and by extension, the Museum director and curators - doesn't see the egregious associations for the performers, who, though willing, will be exploited nonetheless. Their desperate voluntarism says something about the generally exploitative conditions of the art world. (Rainer)

And that exploitive art world, in turn, becomes an index of the growing ubiquity of exploitive voluntarism in the greater social totality. However accurate Rainer's critical analysis and intervention into the business-as-usual of the art world, her intervention falls somewhere between blaming the message on the messenger, and mistaking the forest for the trees. Abramovic's strategies of drawing on bodies and minds who are remunerated only by the supposedly "creative agency of the event" is transparent to new modalities of often informal or state/ market unmediated work (these days casually denominated by a variety of ill-fitting terms from service industry to gig economy) as the industrial cycle of accumulation in North America (1949-1973) in which commodity production was central gave way to a service economy in the era of outsourcing and cheaper labor extracted for commodity production elsewhere. As Marina Vishmidt has recently argued, "post-object art forms such as performance forecast a shift to self-performance as the evaluative prism for all labor" (19). She continues to draw a much larger conclusion from contemporary art work, seeing in it the articulation of the totality of the current labor-to-capital relationship, where "the blurring between service sector and its appearance in the institution of art either in representational or in performative ways, but also on the reliance of that institution, and the broader dimensions of the 'creative industries' is, however edgy its appearance, utterly reflective in the most vulgar sense" (31-32). In this case, the vulgarity is not the fault of a methodological approach; sadly, this "vulgarity" exists in the field of social relations and their mediation in cultural form: "As has been observed in recent curatorial and art critical interventions, the figure of the artist as a service provider rather than as a maker of things is seen to coincide with the transitions from goods to services in economic primacy in the west" (28).

As I have begun to argue, the social synthesis reiterated in the transactional moment, a kind of social contract at the register of the economic and biopolitical, however much an "open secret," is shown to function as a shared condition that nonetheless distinguishes surplus populations from those whose lives are deemed necessary enough to capital to be replicated, to let live. Art in the neo-liberal age, it turns out, is the most vivid index of this fault line that joins and differentiates surplus from the replicable.

\section{$* * *$}

Before turning to the conjuncture of complicitous and antagonistic conditions that enable Sierra's transactional strategy, the work's audience and composition bear a moment of pause. The charm of Venice and the sophistication of the $49^{\text {th }}$ Biennale could not prevent poverty, uneven global economic conditions, and the legal juridical uncertainties of exclusion and biopolitical control from literally erupting into view in a way at once incidental, banal and utterly spectacular. A demographic of educated, liberal viewers who congregate every two years in Venice was put in the position of having to confront a social reality principle, which they largely dealt with through a deferral to ethics and their failure in contemporary life.

A critic for Le Monde, among others, described Sierra's work in general, and his plan at the 2001 Venice Biennale in particular, the result of an "unpitying cynicism." Meanwhile, various social agencies called his use of refugees inhumane despite the fact that the artist worked with refugee organizations (Spiegler). An admittedly miniscule fraction of that putative public, those who have contributed to the discourse on Sierra's project, is polarized between those who see him as exploitative and those who see him continuing the sixties' legacy of negative critique, the unmasking of false consciousness determined

of this model of art now framed as socially engaged practice, see Bishop's Artificial Hells. Note that Bishop in particular distinguished Sierra from among the conciliatory artists she examines in her now paradigmatic essay "Antagonism and Relational Aesthetics."

${ }^{5}$ Yvonne Rainer's letter was addressed to Abramovic's gallery, specifically to its owner Jeffrey Deitch. Rainer, Douglas Crimp and Taisha Pagget signed it. 
by capitalist ideology, indeed of capitalism understood as an ideology (rather than a structural metabolic). Claire Bishop, in her well-known essay "Antagonism and Relational Aesthetics," concludes: "It is worth bearing in mind that since the late 1970s, older avant-garde rhetorics of opposition and transformation have been frequently replaced by strategies of complicity. What matters is not the complicity but how we receive it. If Tiravanija's work is experienced in a major key, then Sierra's is most definitely minor" (71). Minor, but complicit nonetheless. Bishop argues that Sierra's work differs from relational aesthetics on the basis of its rejection of "open-endedness." At the same time, she notes that while it marks delimited institutional contexts such as immigration or illegal commerce, it also acknowledges the porousness of these boundaries. ${ }^{6}$

The majority of Biennale visitors reacted with shock and disdain for what they perceived to be the abusive opportunism of Sierra's tactic. He paid the illegal workers very little for their participation. Yet this parsimony poses the question: what could ever be an adequate exchange rate for an inscription over the body willed by another agent? Could there ever be compensation for the men's extreme vulnerability to the law? To the fact that they were risking their own place in networks and black market forms of survival in order to legitimate and lend value to Sierra's proper name? Sierra's work, whatever its aesthetic interest may or may not be, and in full acknowledgement of its failure as a critical art practice, much less a social intervention, does raise a few urgently necessary questions about art and work in contemporaneity. I would like to use this work as a jumping off point from which to ask what "resistance," that horizon of social justice with which art is so frequently tasked, would look like in the situation Sierra forcefully highlights, indeed what relationship art work could possibly have to exploitive labor outside of, or other than, its complicitous reproduction.

Race and ethnicity factored on a fundamental and structural level into the scene; no mere accident. And yet taking the measure of this relevance, understanding the structural or causal relationship between race and the politics of remuneration, proves challenging not only because of the spectrum of identities and ethnicities involved staged as "other" to white European identity, but given the fact that the problem of remuneration itself, in the form of the wage or the informal fee, is indifferent to race and ethnicity, as it is indifferent to the social relations making possible the exchange, much less the qualitative features of the goods and services rendered. This transactional indifference must be illuminated before the problem of racialization can begin to be broached.

Late Frankfurt School writer Alfred Sohn-Rethel offers a crystalline analysis of the way in which the financial transaction, the exchange via a non-variable term such as the general equivalent (moneyform) of goods and services in the space of the market, stands at once at the origin of abstraction and of a social synthesis beyond the clan, the community. "The nexus of society is established by the network of exchange and nothing else" (Sohn-Rethel 29). ${ }^{7}$ Now, the way in which Sohn-Rethel derives this first principle of a social cohesion exceeding and often superseding the family, the clan and the community summons the question of "consciousness." Oddly enough, the author's query into the limits of consciousness seems to prefigure or run parallel to those of performance art discourse insofar as performance has queried remuneration and task performance art over the last decades. To return to Sohn-Rethel's critical negotiation with the question of consciousness (a question too frequently dismissed as a bourgeois question a priori by much Marxian discourse), notable is the way in which he situates consciousness as an a priori (in this regard in agreement with Kant, not unlike Theodor Adorno's dependence on the Enlightenment philosopher) but argues that this "given" consciousness is structurally, inevitably, suspended at the moment of material exchange. Surprisingly, it is the action of exchange, not thought, that is deemed and redefined as the abstract term!

In commodity exchange the action and the consciousness of people go separate ways. Only the action is abstract; the consciousness of the actors is not. The abstractness of their action is hidden to the people performing it. The actions of exchange are reduced to strict uniformity, eliminating the differences of people, commodities, locality and date. The uniformity finds expression in the monetary function of one of the commodities acting as the common denominator to all the others. The relations of exchange transacted in a market express themselves in quantitative differences of this uniform denominator as different 'prices' and create a system of social communication of actions performed by individuals in complete independence of one another and oblivious to the socializing effect involved. The pivot of this mode of socialization is the abstraction intrinsic to the action of exchange. The abstraction is the dominating form element of commodity exchange to which we give an even wider significance than Marx did, who was the first to discover it. (Sohn-Rethel, 30; emphasis added)

${ }^{6}$ See also Maimon.

7 See also Sami Khatib's argument in "Sensuous Supra Sensuous," . 
Radicalizing Marx, Sohn-Rethel attributes the term "real abstraction" to this originary source of abstraction in the social field. Here, abstraction functions at the level of social relations and, overturning centuries of basic tenets and presuppositions of Western philosophy, abstraction in social relations not only precedes but is the primary causal factor of abstract thought, again, effectively reversing the lines of cause and effect through which the word "abstraction" is frequently deployed. Commonly, and in an internally differentiated and complex history that might begin with Plato and Aristotle, abstraction is understood to be a function of thinking, which is then projected onto the empirical world. Reversing this derivation of abstraction to replace the primacy of the concept to that of practice, Sohn-Rethel claims: "A derivation of consciousness from social being presupposes a process of abstraction which is part of this being" (18). ${ }^{8}$ Abstraction, then, originates not in "men's minds but in their actions. And yet this does not give 'abstraction' a merely metaphorical meaning. It is abstraction in its precise, literal sense" (20). Abstraction arises in the spatio-temporal sphere of interactions while suspending the specificities of time and space, an observation echoed in Sami Khatib's research, discussed above.

Real abstraction, then, constitutes the conditions within which an "ethics" of the human comes to be at once determined by and suspended by the market. For, while agency as such is not bracketed off-if anything the illusions of free will are facilitated, even enabled, herein-the form of agency summoned in this action is not that of the personal individual, but rather the space-time of the market, itself suspended over non-transactional or "normal" social interactions (Sohn-Rethel 48): "The abstraction belongs to the interrelationship of the exchanging agents and not to the agents themselves. For it is not the individuals who cause the social synthesis but their actions, and their actions do it in such a way that, the moment it happens, the actors know nothing of it" (45).

This impersonal "social mechanism" (50) realizes itself as "a materialism that excludes the historical process" (71). In other words, the slip from people to things occurs at the heart of this moment of unconscious social engagement, an unconscious social synthesis. "But the essence of the postulate of equality in exchange is precisely that it cuts across the gap of experience that separates the exchangers. [...] In this way the relationship between the exchanging persons is transferred to the commodities and expressed as an equality between these objects" (Sohn-Rethel 46). The agent, then, is the market itself.

Reification derives ironically from the fact that "the consciousness of those involved in it is blind to the socially synthetic character of the actions" (61). Reification, then, comes to be second nature in which "mental presence," or consciousness, "cannot be testified by observable objects or facts" (62). This social synthesis, in short, forecloses an ethics of consciousness almost a priori.

Social synthesis reticulated to a form of action enacted on a market that is as indifferent to the thoughts of the individuals involved as to the qualities of the objects exchanged becomes a form, a social form, in and of itself. It forms a technology of the social in which form determines at once consciousness (as other to itself) and social being (also other to itself) (8). Again, ethics are sidelined not through the indifference or maliciousness of the actors in the exchange. Rather, the elision is structural to the act: "In an exchange society based on commodity production, however, the social power has lost its personal character and in its place is an anonymous necessity [...] and has assumed the compelling necessity of an objective social law" (Sohn-Rethel 25). ${ }^{9}$ In other words, although the action of exchange is among people, located in a social matrix, it has taken on a seemingly objective character resembling a second nature that displaces and subsumes in advance any possible intervention on the part of the individuals who comprise that social field.

Sierra's work, not only in 133 Persons Paid, but across his oeuvre and in the better known gestures in that oeuvre such as $250 \mathrm{~cm}$ Line Tattooed on 6 Paid People, rests on the performance of transactional logic by assigning a price for the labor power and/or time of available labor power "afforded" by lives endangered by exposure to the state apparatus that deems them illegally present, useful enough, but not enough to be legally remunerated for their [surplus] labor power. This surplus is delineated by the categories of race and ethnicity; I will return to that problem, nested within that of abstraction.

Sierra's specific transactional logic distinguishes his artistic practice from others of his generation (post-Minimalist and post-conceptual art, a lineage to which I return toward the close of this essay) who address collective exertion without addressing collective labor as a technology comprised of social relations. For instance, Francis Alys's 2002 artwork entitled When Faith Moves Mountains, featured in

${ }^{8}$ Sohn-Rethel himself credits Marx: "The view that abstraction was not the exclusive property of the mind but arises in commodity exchange was first expressed by Marx in the beginning of Capital and earlier in the Critique of Political Economy of 1859, where he speaks of an abstraction other than that of thought" (19). He puts it more bluntly yet: "The unproclaimed theme of Capital and of commodity analysis is in fact the real abstraction uncovered there" (20).

${ }^{9}$ Emphasis mine. 
his 2008 MoMA retrospective, incorporated 500 unpaid volunteers who shoveled sand in the outskirts of Lima, Peru in the midday sun until they collectively moved an enormous sand dune by a few inches. Both projects, Sierra's and Alys's, require the viewer to limn the dissonant relationship among meanings of the word "work": art work, instrumental and creative toil. Labor in this context is especially fraught; it cannot be described by either the classic Marxian narratives of proletarianization nor the terms of critique or resistance we have inherited from the socially engaged art of the present. With the obsolescence of these narratives comes the obsolescence of the regime of visibility, the conditions of social visibility, associated with them. But again, the transactional nature of Sierra's mobilization of exploitive voluntarism differs in its emphasis on the purchase of the men's task performance, or rather, passive availability to the power of the artist's dollar to compel them to endanger themselves.

Staging indifference to any qualities outside of the vulnerability and contingency of the state's immigration law, these bodies on the [black] market demonstrate the extent to which exchange itself, rather than labor, functions as the locus of abstraction. "Abstraction does not spring from labor but from exchange as a particular mode of social interrelationship, and it is through exchange that abstraction imparts itself to labor, making it 'abstract human labor'"(Sohn-Rethel 6). It is the sale and purchase of these men's time, apart from their personhood itself or that for which they are paid, that reiterates a primary abstraction. This, in turn, is marked and marked as vulnerable, now to a second order of abstraction: the law.

Sierra's 133 Persons Paid to have Their Hair Dyed Blonde does not, however, (as noted earlier in this essay) traffic in the exchange of commodity goods. It traffics in people. And this ontological shift from things to persons re/marks the conditions of reification marked first by performance art practices, while heightening both its brutality and its contradiction. This is to say that it rehearses the violence of reification by dramatizing its terms. Beyond rehearsal and demonstration, however, the transition from things to persons (a word that comprises the title) tells us something about the internal historicity of capital itself. Sierra isolates one variable: the exchange of human capacity. As a reminder, Sohn-Rethel shows us that "it is the action of exchange and the action alone that is abstract. The consciousness and the action of people part company in exchange and go different ways [...] one could say that the abstractness of their action is beyond realization by the actors because their very consciousness stands in the way" (26-7). Sierra locates this un/consciousness as a collective structural condition, a cruelty everywhere and nowhere in particular, part of the social synthesis of everyday life with or without the framing device that is "art."

The question that emerges, however, is that of race and how race adjudicates the uneven value of human life. The second question, to which I will first turn, is of how this movement of cruelty happens in a cultural milieu that identifies itself as ethical, progressive, often liberal and democratic. And to begin to broach this entails seeing "abstraction" as a process, an operation and a social technology, rather than a qualification of things. "The chief result is money in which abstractness assumes a separate embodiment. Then, however, 'the movement through which the process has been mediated vanishes in its own result, leaving no trace behind"' (Marx qtd Sohn-Rethel 28). This movement itself and the transformations it effects are the "object" of inquiry.

\section{The Totality and the Limits of Intersectionality}

Sierra's cruel abstraction dramatizes, mimetically exacerbates and prefigures those cruel abstractions. Race and ethnicity played a central, pivotal role in this sadistic demonstration of the structural conditions of [abstract] everyday life. They functioned as indices of a political economic crisis at the conjuncture of the global market and the nation-state apparatus. But this poses the question of identity and politics. We are looking, then, at an intersection, a conjuncture in which identity and a relation to economic survival come to be mutually constitutive-as determined by the state. The men deemed illegal by the state and therefore barred from access to earning a wage are then compelled to seek forms of selfsupport outside the law. Their contingence on a legal and juridical status barring them from legal work depends in turn on their social-political position as migrants from elsewhere, outside the fold of Europe. While this circuit of contingencies with relation to the law takes place outside the sphere of appearances, the appearances that the work does summon-dark hair dyed blonde-it is an index of the abstract symbolic terrain of law and its enforcement in administrative bureaucracy, or the domain of the state apparatus. Where, then, in this play of appearances and subject-positions does "identity" factor, if at all? How might it be possible to locate capitalism's impersonal brutality and indifference to social specificity while, in refusal of capitalism's dictate, attending to the racial and ethnic composition of the men? What language might be called on to describe the all too common but inarticulable nexus to which we bear witness, in which social injustice, exploitation and oppression are compounded, one on the other? 
"Intersectionality" is a term the Black feminist scholar Kimberlé Crenshaw coined to contain and synthesize the contradictions that surfaced in a court case originating with factory floor workers at the car manufacturer GM. This labor dispute was initiated by the company's black women workers and seemed to open onto labor struggles related to gender and race, nested within traditional labor struggles. Crenshaw inaugurated the term "intersectionality" as a way to think the conjuncture of the need for a Marxist critique, an analysis of race and finally a feminist politics. The term has been subsequently elaborated into a kind of academic methodology, used as a key term in political struggles as well as in the academy, despite its having originated from protests on the factory floor at GM, through which to conceptualize the confrontation and antagonism of numerous social injustices. Yet it falls under critique in turn for not only compromising the primacy of any one struggle-that of a politics of gender equity or that of the antagonism in the labor-capital dynamic-but for the way in which it unwittingly tends to a politics of particularization, fragmentation, atomization rather than a way to recompose resistance as a class composed of myriad difference. It is unable to somehow to hold the totality of the way in which each current is at once constituted by and constitutive of capitalist social relations within any given moment of capitalism's historicity. Otherwise put, the discourse of intersectionality cannot contain the multiplicity of contradictions that form a kind of open matrix, a warp and weft of social aporias, each in turn emerging from historically determined struggles (diachronically), each situated within differing subject positions (synchronically), all of whom work on the factory floor. These, in turn, arrive to the door of the factory via very different relationships to the history of capital; many are set into structural antagonism.

Returning to the scene of Crenshaw's illumination: can intersectionality offer us a means through which to think at once both the evident cruelty and the normalcy of Sierra's framing of a social reality itself at once inhumane and utterly naturalized within the social order? In "Mapping Social Reproduction Theory," Tithi Bhattacharya offers a satisfying solution. She argues that:

Intersectionality theory shows us a world where race, gender, and other oppressions "intersect," thereby producing a reality that is latticed-a sum total of different parts. At first glance this "whole," as an aggregate of different parts, may be the same as the Hegelian-Marxist conception of totality. An elementary question about the nature of intersections, however, reveals the distinction between these two concepts. If, as intersectionality tells us, race and gender (or race and class) intersect like two streets, then surely they are two separate streets, each with its own specificities. What then is the logic of their intersection? I suggest that the logic and conclusions of intersectional theorists actually contradict their methodology. (17)

Recall that visibility itself became the protagonist of 133 Persons Paid to Have Their Hair Dyed Blond. While it literally highlighted heads, the cruelty of Sierra's gesture highlighted a wider structure of habituated systemic brutality: the global exhibitionary order founded on transient bodies, bodies contingent upon and vulnerable to abstracted social relations generated by an ever more complexly mediated liaison between capital and labor. ${ }^{10}$ Political scientist Timothy Mitchell has argued that an exhibitionary order was developed in the world fairs of the mid to late nineteenth century, starting with the London World's Fair of 1851, running through the Expositions Universelles in Paris in the 1860s and 1870s. He makes the case that this exhibitionary order forges the framework, template even, for numerous art world fairs and biennials in this our contemporaneity (Mitchell). My intervention here consists only of the claim that the capitalist metabolic extracting value from bodies and resources, mediating it in the social and cultural field, has changed all the more to stay the same, to maintain hegemony. The manifestation of the exhibitionary order distributing bodies, goods, and services has therefore also changed, however much its basic structure, forged in the nineteenth century industrial crucible, remains. How might we trace its etiology? How do art works clarify, if not prefigure, capital flight from core to periphery and how does this ramify in the burgeoning service sector of capitalist value-production?

Sierra's act of visual emphasis is not synonymous with exposure or unveiling, ${ }^{11}$ the primary modus operandi of another (other than performance which continues on) genre of post-minimalist art: the critique of institutions. ${ }^{12} 133$ Persons framed that which the visual regime of the exhibit in 2001 both

10 The term "exhibitionary order" is Timothy Mitchell's.

11 Vered Maimon. "The Third Citizen." The question of democratic transparency and critical opacity has become something of an autonomous discourse, currently categorized as "invisibility studies." See the collection Invisibility Studies.

${ }^{12}$ See Alex Alberro's edited anthology on this movement in the art of the Sixties and Seventies in North America and Europe, known as "The Critique of Institutions," much of which revolved around ideology critique and the 
depends on and dismisses: the uneven value of the human. Sierra is not making the traditional enlightenment (Habermassian) argument that social communicative transparency will save the day, so to speak. Because the work Sierra and others of his generation do is responding to a social fabric organized by forms of both transparent control and opaque disciplinary orders (Deleuze), that which is isolated from view is not hidden as such, as might be expected of an actually operative "civil society," any more than the "hidden abode of production" to which Marx famously refers in Capital is actually technically hidden. It is hidden in plain sight, in the visual landscape, and yet absent in the consciousness of the properties, of the citizen-consumer; but this absence to consciousness at stake in much Marxian and Frankfurt school discourse is no longer a matter of making the unknown known. Exposure is not the point. The open secret of asymmetrical human value within capital is at stake. The uneven value of human life, the social relations attendant therein, and what it means to make art in an age of austerity and restructuring in the aftermath of the Keynesian state comes under scrutiny, part of the total social "picture" (Shaikh). The problem of interchangeability brought to bear by the ultimate commodity that is labor power under a new and young industrial modernity has transitioned now to mass disposability partially and provisionally tested through racialized discourses of people.

Let us turn once more to the scene at the Arsenale in Venice in 2001. Whatever the good intentions on the part of artists, curators, critics, viewers and culture industry workers at all levels of rank and file, Venice, like many international mega shows, operates in such a way that institutional self-reflection on the set of geopolitical and economic conditions upon which art events depend is willfully if unconsciously scotomized. In this context, Sierra's gesture acts like a cut in the fabric of reality. ${ }^{13}$ This "cut" offers a modality of analysis that is not mappable in the current available discourses of ethical social justice. While we have heard a great deal of late about art in relationship to social justice (Tania Brugeira, Pablo Helguera, Grant Kester, Yates Mckee, Nato Thompson), often organized around the theme of "participation" (whatever one may make of the notion of autonomy), the social justice turn in art mistakes cause and consequence, failing to account for the fundamental transition in the shifting internal dynamic of capital itself as it moves from former cores to former peripheries, requiring different forms of extraction as it goes. More specifically, this kind of discourse-the social justice turn-does not factor labor, legal or illegal, into its narrative of injustice nor in its definition of justice. Overlooked is both the source of wealth in value productive labor, the circulation of this wealth in the ever widening labyrinth of global finance, and the way in which the violent social de- and re-composition demanded by capital both deracinates and reintegrates social relations globally. Above all, the language of social justice misses social abstraction and the social technologies that both constitute and are constitutive of it: the site of exchange and the contractually (i.e. arbitrary, but socially determined) act of exchange which appears conscious but suspends agency a priori. ${ }^{14}$

Art fairs, however much a construct of the nineteenth century, are, in the contemporary globalized world located everywhere and seemingly nowhere in particular, from Venice to Gwanju to Karachi. What appeared to be about competition among nation states articulated culturally (The London Fair, the Paris Expositions) was always structurally reticulated to the phenomenon of globalization. If anything, this un/conscious self-reflexivity of the inevitability of globalized totalization under capitalism is inscribed in their titles: London World's Fair, Exposition Universelle. In order for the relationship of the art work to the social field with which it dialectically negotiates to begin to be understood, much less appropriated into the critic's own political agenda, its relationship to the source and circulation of its own funding

premise that the museum is an Ideological State Apparatus (Althusser). On the politics of exposure, see also Alberro's "The Turn of The Screw."

${ }^{13}$ For a succinct thorough explanation of the current political economic conjuncture known as "globalization," see Postone. As elaborated by Giovanni Arrighi in The Long Twentieth Century, the problem of "restructuring" after the oil crisis of 1973 was already implicit and inevitable in the reorganization of political and economic power during Bretton-Woods. Arrighi makes the same argument in The Geometry of Empire. The Bretton-Woods agreement between Europe and the United States, designed with the intention of warding off Communism during The Cold War, re-organized global dynamics in the interest of US economic power. But the economic base subtending this power in American profit rates began to decline at the close of Bretton Woods (1973). See also Brenner. The bestknown and certainly most popular text in English on the organization of the world in the interest of global neoimperial domination is Antonio Negri and Michael Hardt's Empire. That thesis, however, displaces forms of capitalist reconsolidation, which is neocolonialism, with issues of constitutionality and the limits of national and international law. On this, see David Harvey. The strongest recent analysis of the relationship of neoliberalism in the global era to art is Marina Vishmidt's Speculation.

${ }^{14}$ The most recent in a genealogy of discourse attempting to grasp why despite a surplus of analysis about the discontents of capitalism it is collectively replicated daily and resisted relatively little is Samo Tomsic's work. See his The Capitalist Unconscious. 
must be taken into account. The question of the global underclass, in turn, becomes also a question of surplus populations, those bodies deemed disposable because no longer structurally necessary to capitalist value production. ${ }^{15}$

Sierra does not take up the problem of labor from the perspective of ethics or an interest in social reform inherited from the progressive cultural practices of the Sixties, but rather as a structurally inevitable necessary condition of art making and exhibiting now. In this, he might precede the modality of analysis currently saturating discourse. This structural condition acts as both limit and spur to the very possibility of art now.

Having discussed the current art historical discourse about the social justice turn in art, a category in which, as previously mentioned, Sierra is not included, it will be helpful now to turn to seemingly thematically comparable works of previous generations of critical art practice in order to differentiate Sierra's project from the now canonized models of art making whose continual reception contributes to its misrecognition. Already in 1968 in Paris, Daniel Buren had set into action the relationship between remuneration, art, and personhood. A group of sandwich men wore boards on which Buren's idiomatic white and colored stripes were painted at the equally idiomatic (think: branding) $8.7 \mathrm{~cm}$ intervals. This part advertisement, part artwork, unmasked commoditization of the human. After Marx, the perennial question of the commodity and its expropriation of subjectivity has been posed repeatedly beginning with Siegfried Kracauer's "Little Shop Girls Go to the Movies," in Mass Ornament and Walter Benjamin's poetic exploration of nineteenth century Parisian Arcades in which a homeless proletariat, the clochards, worked as living advertisements, blurring the line between animate and inanimate (Buck-Morss 306 ). ${ }^{16}$ Buren's clochards literalize Marx's observation that capital structurally renders subjects objects by making persons contingent on a wage relation in which they cannot afford the results of their own labor, while symmetrically making of objects subjects due to the mystification and power of the commodity fetish. Buren's men for hire performed the paradox of circulating the central and most visible social message of capital-the advertisement-while themselves remaining invisible. Although it would look as though Buren was onto something more fundamental than the role of the museum as such, the work has been understood as part of the Critique of Institutions in which art practices took their own institutional condition of possibility as a problem to be explored, without looking further into the role those institutions played in relation to the capitalist valorization process it echoed. Hans Haacke came closest to locating the relationship between museums and money in numerous pieces among his body of work, notably when he identified slum lords among MoMA's board members, but again, as Vered Maimon points out in her study of what differentiates the generation of Sierra and those in his historical and discursive cohort such as Francis Alÿs is the insignificance of any enlightenment aspiration. Ideology critique is beside the point. The former public sphere is now saturated with an excess of analysis and no way forward.

Sierra's framing device supersedes those of The Critique of Institutions by shifting emphasis from the institution, understood as an ideological apparatus, to microcosms embedded in and reproducing the larger system of circulation dependent on changes internal to capitalist modes of production. This line of inquiry was begun by the erstwhile painter Marcel Duchamp in 1915. The Duchampian readymade, which Rosalind Krauss has referred to as a "theoretical object," stands also as prefigurative research into not only the congealed labor tethered to seduction and desire of commodity fetishism, but is also prefigurative of a new and structurally American managerial class mediating the labor-capital dynamic (Lazzarato). Yet while subsequent generations of artists have revisited and reiterated this theoretical object, and while it has generated a vast corpus of literature, (Krauss, Nesbit, Joselit, Demos, Baker, Roberts, Lazzarato) generationally sequential artistic inquiry into the limits of art via this theoretical object have allowed its primary question of labor and value (and the falling value of labor power) to fall by the wayside.

To repeat, Sierra's work is not critical of the system it analyzes other than to render it brutally stark and to demonstrate the degree to which very little differentiates working conditions in modern liberal democracy from the same depiction of premodern economies of servitude it believes itself to have replaced. If anything Buren's practice happened at the very moment capital was about to reconsolidate after beginning to free itself of the social buy-out offered by Keynes-inspired worker compensation

${ }^{15}$ See Shaikh, Competition, Conflict, Crisis, in particular the passages on surplus labor, notably Chapter Six, Part Six entitled "Theories of Aggregate Profit in Various Schools" in "Capital and Profit."

${ }^{16}$ Significantly, Buck-Morss juxtaposes a 1930s photograph of a sandwich man in Paris with a photograph, drawn from the same period, of a German Jewish man forced to walk without shoes and pants between two policemen down a boulevard. He carries a board, not unlike the advertisements the sandwich men wore, situating his relationship to Germany, the state: "I am a Jew but I have no complaints about the Nazis" (6). 
packages, such that cultural critique became merely a form of mediation allowing capital and labor to be ever more deeply integrated. Italian Workerist theorist Mario Tronti has noted that May '68 was a cultural revolution that deflected a deeper reaction (127).

At around the same time as Buren's interrogation of institutional authority, a number of artists were explicitly identifying with the figure of the worker. As Julia Bryan Wilson has shown in Art Workers, the rise of New Left social movements in the Sixties in the United States saw a number of artists such as Carl Andre and Robert Morris actively conjugating work-as in art-with work, with labor power for sale on a market. These artists attempted to present the labor-capital dynamic as one in which the worker (or manager) had agency, enough agency to generate exceptional forms of creative capacity, and who in turn would continue to identify with the worker. Andre and Morris, in other words, naively believe in creative agency, one based on a model of the subject capable of willfully moving from the subject position of the artist to the worker and back again in a kind of free self-determination unconstrained by history, process or culture. Questions of identity and appropriation aside, this contradiction, or naïve theater of identity, occurred at the very same moment that theorists of the work [of art] were declaring the death of the author or questioning the category (Barthes, Foucault), while theorists of work framed by inquiries into class consciousness of the New Left began to posit the intellectual worker, the student or artist, as a possible agent of historical change. In both cases, the worker and the notion of work failed to be submitted to the kind of analysis subsequently made possible by anti-work theorists of labor (Panzieri, Negri, Bologna et al. and more recently Mattick, Shaikh, Weeks and others).

The politicization of artistic labor, in short, happened at the very moment that labor itself was changing, such that the artist was bound to identify with a vanishing subject position, literally and figuratively. Robert Morris for instance stated that "matter as matter rather than as symbol is a conscious political position I think, essentially Marxist" as quoted by Theresa Schwartz in art in America in 1971. The trouble is that precisely that model of literalist materialism and literal deferral to the worker happened when the industrial worker subject, as evoked by Morris in numerous images of heroic physical labor, was being relocated in much cheaper labor pools in the global south, those geopolitics sources of cheap labor and of problematic immigration patterns to the global north and former core.

Paradoxically, as I have argued elsewhere, the logic of seriality and recursive structure with which these artists were engaged were symptoms of a logic of value production yielding to a new model of capitalist integration predicated increasingly on deskilling on the one hand and outsourcing on the other, between 1968 and 1971 . The wish to elaborate a practice which eliminated or diminished the artist's hand and substitute it with factory production was already behind the changes taking place, which was the elimination of the worker altogether by moving the locus of labor to places where labor was not protected by the same regulative system put in place by the welfare state established during the 1930s and the financialization of capital in the 1970s, both of which placed the onus of reproducing hegemony on the consumer, not the worker. Morris neither acknowledges the duress of the hero-worker occurring already by the early 70s, nor does he destabilize the value system. In hindsight, Morris's gestures are not only piteously touching in their identification with a subject position soon to become purely mythical-the robust worker-but truly melancholic for an entire era in which it seemed possible to locate class and the very subjects of revolutionary class consciousness in the subject of history, a nostalgia whose reactionary undercurrents we have seen in full force in the last decade. Notably, every account of Sierra's trajectory as an artist notes his early intellectual debt to and influence by Minimalism. ${ }^{17}$

Turning from the nostalgia of an industrial era made possible by the heroic American worker who, in turn, was offered not only a living wage but a benefits package allowing for the daily replication of himself and that of a family, Sierra highlights the regimes of visibility and invisibility that describe remunerated (if not waged) work in the twenty first century. Sierra's work conjugates the current conditions of labor power on the market under a "neo liberalism" international-statist order managed by the IMF in which, when it comes to the small change of individual lives, the state has the final say on the distribution of "rights"-to live or die. This entwinement, a co-determination described more accurately by social reproduction theory than intersectionality, renders each of the terms class, race, gender in one another's blind spots, a triangulation susceptible to perceptual distortion. Articulating it in what strikes me as the most complete if most radical definition of "neo-liberalism" to date, Vishmidt notes the evacuated political agency of labor in the face of capital: "the biopolitical harnessing of human survival to capital's valorization, with most institutions of mediation and compensation increasingly on the wane" (Speculation 11). Vishmidt is delineating the role of the artist as "creative worker," the subject who must self-valorize in every sense of the terms, crossing the lines of autonomy and heteronomy in

${ }^{17}$ See Sileo and Henke; and Heartney and Obrist. 
relationship to the value-form, while Sierra continues to emphasize the part played by race-a specifically racialized neoliberal capitalist order that sorts those who can die and those permitted to live, distributing this order through the capitalist categories instrumental to the replication of the necessary order for this form of labor power extraction, versus those disposable to it.

Art posits itself as a place to limn or probe the coordinates of totality in its prefiguration. Sierra's gestures recognize labor as a matrix, a system and a social technology rather than a set of actions or recognizable activities, producing subjectivity as much as commodity objects, but producing it as object, rendering being a person, much less that of the privileged creative subject, such as the artist, more and more unlikely. It is against this backdrop that naïve enactments of labor become worrisome. Of interest to me, in this regard, are recent attempts on the part of artists to explicitly address the problem of labor, of making, in a cultural sphere. While it may be self-evident enough that, as Theodor Adorno might put it, "There is no material content, no formal category of artistic creation, however mysteriously transmitted and itself unaware of the process, which did not originate from the empirical reality from which it breaks" (190), I would argue that the rubric of social justice has done much to obscure the relation, the chain of mediation, between the work and its empirical reality. The horizon, or what reality might mean today, is itself at stake.

\section{Works Cited}

Adorno, Theodore. "Commitment." Aesthetics and Politics. Verso, 2007.

Alberro, Alexander. "The Turn of the Screw: Daniel Buren, Dan Flavin, and the Sixth International Guggenheim Exhibition." October, vol. 80, Spring 1997, pp. 61-2.

Alberro, Alexander and Blake Stimpson. Institutional Critique: An Anthology of Artists Writings, edited by Alexander Alberro and Blake Stimpson, The MIT Press, 2009.

Arrighi, Giovanni. The Long Twentieth Century, Verso, 1996.

---. The Geometry of Empire, translated by Patrick Camiller, Verso, 1983.

Belshaw, Douglas John. Colonization and Community: The Vancouver Island Coalfield and the Making of the British Columbian Working Class. McGill-Queen's University Press, 2004.

Bhattacharya, Tithi. "Mapping Social Reproduction Theory." Social Reproduction Theory: Remapping Class, Recentering Oppression, edited by Tithi Bhattacharya, Pluto Press, 2017, pp.1-20.

Bishop, Claire. Artificial Hells: Participatory Art and The Politics of Spectatorship. Verso, 2012.

---. "Antagonism and Relational Aesthetics," October, 110, Fall 2004, 51-79.

Brenner, Robert. "Persistent Stagnation, 1973-93." The Boom and the Bubble. Verso, 2002, pp. 7-47.

Buck-Morss, Susan. The Dialectics of Seeing: Walter Benjamin and the Arcades Project. The MIT Press, 1986.

Crenshaw, Kimberlé. "Mapping the Margins: Intersectionality, Identity Politics, and Violence Against Women of Color," Stanford Law Review, vol. 43, no. 6, Jul. 1991, pp. 1241-1299.

Deleuze, Gilles. "Post-Script on the Societies of Control," October, vol. 59, Winter 1992, pp. 3-7.

Foster, Hal. "Mimetic." Bad New Days. Verso, 2017.

Goldberg, Roselee. Performance Art From Futurism to the $21^{\text {st }}$ Century. Thames and Hudson, 2011.

Gonzalez, Maya. "The Gendered Circuit: Reading The Arcane of Reproduction." Viewpoint Magazine. Special Issue on The Workers' Inquiry. September 28, 2013.

Hansen, Bue Rübner. "Surplus Population, Social Reproduction and the Problem of Class Formation." Viewpoint Magazine. October 31, 2015. https://viewpointmag.com/2015/10/31/surplus-population-social-reproductionand-the-problem-of-class-formation/

Harvey, David. A Brief History of Neoliberalism. Oxford University Press, 2007.

Heartney, Eleanor and Hans Ulrich Obrist. Santiago Sierra: The Back Cone, Monument to Civil Disobedience. Reykjavik Art Museum, 2013.

James, Selma and Mariarosa Dalla Costa. The Power of Women and the Subversion of the Community. Falling Water Press, 1972.

Jones, Amelia. Body Art: Performing the Subject. University of Minnesota Press, 1998.

Khatib, Sami. "'Sensuous Supra-Sensuous:' The Aesthetics of Real Abstraction." Aesthetic Marx, edited by Samir Gandesha and Johan Hartle, Bloomsbury Press, 2017, pp. 49-72.

Kinkle, Jeff and Alberto Toscano. Cartographies of the Absolute. Zero Books, 2015.

Kracauer, Siegfried. Mass Ornament, Weimar Essays, translated and edited by Thomas. Y. Levin, Harvard University Press, 1995.

Lazzarato, Maurizio. Experimental Politics: Work, Welfare, Creativity in the Neoliberal Age, edited by Jeremy Gilbert, The MIT Press, 2017.

Maimon, Verad. "The Third Citizen: On Models of Criticality in Contemporary Artistic Practices," October, vol. 129, Summer 2009, pp. 85-112.

Mitchell, Timothy. "The World as Exhibition" Comparative Studies in Society and History, vol. 31, no. 2, April 1989, pp. 217-236.

Negri, Antonio and Michael Hardt. Empire. Harvard University Press, 2000. 
Postone, Moishe. "Theorizing the Contemporary World: Robert Brenner, Giovanni Arrighi, David Harvey." Political Economy of the Present and Possible Global Futures, edited by Robert Albritton, Bob Jessop, Richard Westra, Anthem Press, 2016, pp. 7-24.

Rainer, Yvonne. "To Jeffrey Deitch," 9 November, 2011. Open Letter. Published by The Performance Club on November 11, 2011: http://theperformanceclub.org/2011/11/yvonne-rainer-douglas-crimp-and-taisha-paggettblast-marina-abramovic-and-moca-la/

Roberts, John. "The Commodity, The Readymade and the Value-Form." The Intangibilities of Form: Skill and Deskilling in Art After the Readymade. Verso, 2007, pp. 21-47.

Rodenbeck, Judith. Radical Prototypes: Allan Kaprow and The Invention of Happenings. The MIT Press, 2014.

Shaikh, Anwar. Competition, Conflict, Crisis. Oxford University Press, 2016.

Sileo, Diego and Lutz Henke. Santiago Sierra: Mea Culpa. Silvana Editoriale, 2017.

Sohn-Rethel, Alfred. Intellectual and Manual Labor: A Critique of Epistemology. Macmillan Press, 1978.

Spiegler, Marc. "When Human Beings are the Canvas." Art News. June 2003.

The Invisible Committee. Now. The MIT Press, 2017.

Tronti, Mario. "Our Operaismo." New Left Review, translated by Eleanor Chiari, no. 73, January-February 2012, pp. 119-139.

Veel, Kristen and Henriette Steiner. Invisibility Studies: Surveillance, Transparency and the Hidden in Contemporary Culture, edited by Henriette Steiner and Kristin Veel, Bern: Peter Lang, 2015.

Vishmidt, Marina. Speculation as a Mode of Production in Art and Capital. Brill, 2018.

---. "Human Capital or Toxic Asset: After the Wage". Mute Magazine, January 10, 2010, http://www.metamute.org/community/your-posts/human-capital-or-toxic-asset-after-wage.

Author's profile: Jaleh Mansoor is an associate professor of Art History at UBC whose areas of teaching and research include Modernism and the avant-gardes, European art since 1945, Marxism and Frankfurt School Theory, Formalism, Marxist Feminism and social reproduction theory. Mansoor's first monographic book, Marshall Plan Modernism: Italian Postwar Abstraction and the Beginnings of Autonomia was published by Duke University Press in 2016. <jalehm@mail.ubc.ca> 